\title{
Late onset Li-Fraumeni Syndrome with bilateral breast cancer and other malignancies: case report and review of the literature
}

\author{
Karin Kast ${ }^{1 *}$, Mechthild Krause ${ }^{2}$, Markus Schuler ${ }^{3}$, Katrin Friedrich ${ }^{4}$, Barbara Thamm ${ }^{5}$, Andrea Bier ${ }^{6}$, \\ Wolfgang Distler ${ }^{1}$ and Stefan Krüger ${ }^{6}$
}

\begin{abstract}
Background: Li-Fraumeni-Syndrome (LFS) is an autosomal-dominant, inherited tumour predisposition syndrome associated with heterozygous germline mutations in the TP53 gene. Patients with LFS are at a high risk to develop early-onset breast cancer and multiple malignancies, among which sarcomas are the most common. A high incidence of childhood tumours and close to 100\% penetrance has been described. Knowledge of the genetic status of the TP53 gene in these patients is critical not only due to the increased risk of malignancies, but also because of the therapeutic implications, since a higher rate of radiation-induced secondary tumours in these patients has been observed.
\end{abstract}

Case report: We report a patient with LFS harbouring heterozygous, pathogenic TP53 germline mutation, who was affected by four synchronous malignancies at the age of 40: a myxofibrosarcoma of the right upper arm, bilateral breast cancer and a periadrenal liposarcoma. Radiological treatments and a surveillance program were adjusted according to recommendations for LFS patients.

Conclusion: Management of tumour treatment of patients with LFS is different to the general population because of their risk for secondary cancers in the radiation field. Screening procedures should take a possibly elevated risk for radiation induced cancer into account.

Keywords: Li-Fraumeni-Syndrome, LFS, TP53, Secondary cancer, Treatment

\section{Background}

Li-Fraumeni-Syndrome (LFS; OMIM \#151623) is a rare autosomal-dominant, inherited tumour predisposition syndrome associated with an increased risk of a variety of malignancies. Recent statistical analyses stress the relevance of four "core" cancers which account for $77 \%$ of all associated cancers: breast cancer, sarcomas, brain tumours and adrenocortical carcinoma (ACC) [1]. LFS is characterized by high penetrance [2] and early-onset tumours [3,4]. The lifetime risk is higher, and age of onset is earlier in women compared to men [5,6]. Several criteria, classical and Li-Fraumeni-like (LFL), have been developed to identify patients and families with LFS [4,7-11] (Table 1).

\footnotetext{
* Correspondence: karin.kast@uniklinikum-dresden.de

'Klinik und Poliklinik für Frauenheilkunde und Geburtshilfe, Universitätsklinikum Carl Gustav Carus, Fetscherstr, 74, 01307 Dresden, Germany

Full list of author information is available at the end of the article
}

LFS is associated with heterozygous germline mutations in the tumor protein p53 (TP53) tumour suppressor gene. Mutations in TP53 are detected in 80\% of individuals fulfilling the classic LFS criteria and $\sim 30 \%$ of those fulfilling the LFL criteria (Table 1) [2,12-14]. In order to increase the sensitivity of detection, the Chompret criteria were adjusted in 2009, for age and tumour spectrum parameters (Table 2). Genetic testing for TP53 is recommended by the National Comprehensive Cancer Network (NCCN, http:// www.nccn.org) in accordance with the Chompret criteria, or in any breast cancer patient $<30$ years of age testing negative test for $B R C A 1$ and $B R C A 2$ mutations.

TP53 encodes a transcription factor implicated in cellcycle control, apoptosis and genomic stability $[15,16]$. Impaired TP53 function may not only influence tumour response to radiotherapy and chemotherapy, but also confers an elevated risk for therapy-induced secondary 
Table 1 Description of different criteria for Li-Fraumeni Syndrome (LFS) or Li-Fraumeni-like (LFL) Syndrome

\begin{tabular}{|c|c|c|}
\hline & Criteria & Description \\
\hline \multirow[t]{3}{*}{ LFS classic } & Li-Fraumeni [4] & Proband diagnosed with sarcoma before 45 years, AND \\
\hline & & - a first-degree relative with cancer before 45 years, AND \\
\hline & & $\begin{array}{l}\text { - another first- or second-degree relative with any cancer diagnosed } \\
\text { under the age of } 45 \text { years or with sarcoma at any age }\end{array}$ \\
\hline \multirow[t]{5}{*}{ LFL } & Chompret original [9] & $\begin{array}{l}\text { 1. Proband with a "core cancer" before } 36 \text { years, AND at least one } \\
\text { first- or second-degree relative with }\end{array}$ \\
\hline & & $\begin{array}{l}\text { - cancer (other than breast cancer if the proband has breast cancer) } \\
\text { under the age of } 46 \text { years OR }\end{array}$ \\
\hline & & - multiple primaries at any age \\
\hline & & $\begin{array}{l}\text { 2. Proband with multiple primary tumours, two of which are } \\
\text { "core cancers", with the initial cancer occurring before } 36 \text { years, } \\
\text { regardless of the family history }\end{array}$ \\
\hline & & $\begin{array}{l}\text { 3. Proband with adrenocortical carcinoma at any age of onset, } \\
\text { regardless of the family history }\end{array}$ \\
\hline \multirow[t]{5}{*}{ LFL } & Chompret 2009 update [10] & $\begin{array}{l}\text { 1. Proband with a tumour belonging to the LFS tumour spectrum } \\
\text { before } 46 \text { years, AND }\end{array}$ \\
\hline & & $\begin{array}{l}\text { - at least one first- or second-degree relative with cancer } \\
\text { (other than breast cancer if the proband has breast cancer) } \\
\text { under the age of } 56 \text { years OR }\end{array}$ \\
\hline & & - a relative with multiple primaries at any age \\
\hline & & $\begin{array}{l}\text { 2. Proband with multiple primary tumours (except multiple breast tumours), } \\
\text { two of which belong to the LFS spectrum, with the initial cancer occurring } \\
\text { before the age of } 46 \text { years, regardless of the family history }\end{array}$ \\
\hline & & $\begin{array}{l}\text { 3. Proband with adrenocortical carcinoma or plexus tumour at any age of onset, } \\
\text { regardless of the family history }\end{array}$ \\
\hline \multirow[t]{3}{*}{ LFL } & Birch [6] & $\begin{array}{l}\text { Proband with any childhood cancer or sarcoma, brain tumour, } \\
\text { or adrenocortical carcinoma diagnosed under } 45 \text { years of age, AND }\end{array}$ \\
\hline & & $\begin{array}{l}\text { - a first- or second-degree relative with a typical LFS-related cancer } \\
\text { ("core cancers" and leukaemia) diagnosed at any age, AND }\end{array}$ \\
\hline & & $\begin{array}{l}\text { - a first- or second-degree relative in the same genetic lineage with any } \\
\text { cancer diagnosed under the age of } 60 \text { years }\end{array}$ \\
\hline LFL & Eeles [7] & $\begin{array}{l}\text { Two different tumours that are "core cancers" or leukaemia in first- or } \\
\text { second-degree relatives at any age }\end{array}$ \\
\hline Li-Fraumeni Syndrome & NCCN-Guidelines since 2010 & Classic LFS-Criteria OR LFL according to Chompret 2001/2009 OR \\
\hline
\end{tabular}

Early onset breast cancer: Individual with breast cancer $<30$ years of age with a negative $B R C A 1 / B R C A 2$ test, especially if there is a family history of sarcoma, brain tumour, adrenocortical carcinoma or chorid plexus carcinoma

Tumour spectrum: Five "core cancers": sarcoma, brain tumour, breast cancer or adrenocortical carcinoma plus e.g. leukaemia, lung bronchoalveolar cancer Abbreviations: NCCN = National Comprehensive Cancer Network.

malignancies and possibly increased sensitivity to lowdose radiation exposure by diagnostic methods $[4,17]$.

We hereby present a case with LFS and relatively late tumour onset, in which a de novo mutation in TP53 was identified. Response to adjuvant therapy, treatment modification as well as further screening modalities in patients with LFS are discussed.

\section{Case presentation}

Myxofibrosarcoma of the right upper arm

In August 2006, a 40-year old female patient was examined for swelling in the lateral side of the right upper arm.
Upon resection, the patient was diagnosed with myxofibrosarcoma. A second resection was performed to achieve tumour-free margins and plastic surgery was performed two times on the damaged area for cosmetic purposes.

Screening for metastatic disease by computer tomography (CT) showed no pulmonary, bone or hepatic metastases, however a lesion $(36 \times 23 \mathrm{~mm}$ diameter $)$, classified as a benign tumour by CT criteria, was detected adjacent to the left adrenal gland. A control CT scan in December 2006 revealed that this lesion had increased in size. Biopsy of the periadrenal tumour indicated a possible mesenchymal tumour, however malignancy was not confirmed. 
Table 2 Chronologic synopsis of case report

\begin{tabular}{|c|c|c|c|c|}
\hline Year / Month & Sarcoma/Carcinoma & Stage & Therapy & Follow up \\
\hline \multirow[t]{3}{*}{ 2006/08 (40 y) } & \multirow{3}{*}{$\begin{array}{l}\text { Myxofibro-sarcoma } \\
\text { right upper arm }\end{array}$} & \multirow[t]{3}{*}{ pT1a, pNx, pMx, G2, R0 } & Incomplete resection, R1, 2006/08 & palpation, \\
\hline & & & Re-Resection, R1, 2006/09 & 12-mo MRI \\
\hline & & & $\begin{array}{l}\text { Re-Re-Resection with musculo-cutaneous } \\
\text { flap 2006/11 }\end{array}$ & \\
\hline \multirow[t]{5}{*}{ 2006/12 (40 y) } & \multirow{5}{*}{$\begin{array}{l}\text { Breast cancer } \\
\text { right side }\end{array}$} & \multirow{5}{*}{$\begin{array}{l}\text { ypT2 ypN1a (2/13) yM0 L0 } \\
\text { V0 R0 yG3, ER IRS 2, } \\
\text { PR IRS 9, Her2neu pos., } \\
\text { IRS 3, invasive ductal carcinoma }\end{array}$} & Neo-adj. CT with 4x FEC, 2007/01-04, & prophylactic \\
\hline & & & Lumpectomy and axillary dissection 2007/05, & mastectomy offered \\
\hline & & & Adj. CT, 4x P 2007/06-08, & 3-mo palpation, \\
\hline & & & Herceptin ${ }^{\circledR} \quad 2007 / 09-2008 / 06$ & 6-mo ultrasound, \\
\hline & & & GnRH Analoga + TAM 07/09-ongoing & 12-mo MRI \\
\hline 2006/12 (40 y) & $\begin{array}{l}\text { Breast cancer } \\
\text { left side }\end{array}$ & $\begin{array}{l}\text { ypT1c ypN1mic (1/17) yM0 } \\
\text { L0 V0 R0 yG3, ER IRS 8, } \\
\text { PR IRS 12, Her2neu pos. IRS 3, } \\
\text { invasive ductal carcinoma }\end{array}$ & see above & see above \\
\hline \multirow[t]{2}{*}{ 2007/05 (40 y) } & \multirow{2}{*}{$\begin{array}{l}\text { Liposarcoma } \\
\text { periadrenal left }\end{array}$} & \multirow{2}{*}{$\begin{array}{l}\text { pT2b pN0 (0/2 LK) pMx L0 V0 G3, } \\
\text { Rx, pleomorph sarcoma }\end{array}$} & Lumbal left adrenalectomy 2007/05, & \multirow[t]{5}{*}{ MRI } \\
\hline & & & Radiation therapy (66 Gy) 2007/08-10 & \\
\hline \multirow[t]{3}{*}{ 2008/05 (41 y) } & \multirow{3}{*}{$\begin{array}{l}\text { Recurrence } \\
\text { Recurrence }\end{array}$} & \multirow{3}{*}{$\begin{array}{l}\text { ypT2 ypN0 (0/14) ypMx G1 } \\
\text { R1(vessel) }\end{array}$} & CT with 2xifos 2008/06, followed by & \\
\hline & & & $\begin{array}{l}\text { Trabectedin, Mini-ICE and Hyperthermia } \\
\text { 2009/01-05 }\end{array}$ & \\
\hline & & & $\begin{array}{l}\text { Compartment resection with hemicolectomy, } \\
\text { splenectomy, partial diaphragm resection and } \\
\text { resection of } 11^{\text {th }} \text { costa 2009/06 }\end{array}$ & \\
\hline $2010 / 06$ & Recurrence & & CT with Trabectedin since 2010/06 & \\
\hline
\end{tabular}

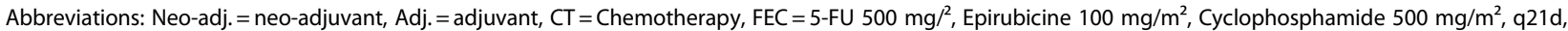
$P=$ Paclitaxel $175 \mathrm{mg} / \mathrm{m}^{2}, \mathrm{q} 21 \mathrm{~d}, \mathrm{TAM}=$ Tamoxifen $^{\circledR}$, Ifos $=$ Ifosfamide, mo= monthly, Mini-ICE = Ifosfamid, Carboplatin, Etoposide.

\section{Bilateral breast cancer}

In addition, suspect bilateral mammary lesions were also diagnosed. Histological examination of biopsies taken from both breast tumours, revealed invasive ductal carcinomas on both sides.

Because of an unfavourable breast-tumour-relation, neoadjuvant chemotherapy was applied. After four cycles of an anthracycline-containing regimen, restaging revealed no significant change in the breast tumours, however progression of the periadrenal mass which extended in diameter to $67 \times 49 \mathrm{~mm}$, was identified by CT scan. Firstly, a bilateral breast-conserving tumour extirpation in combination with bilateral axillary lymphonodectomy was performed. Both carcinomas were positive for oestrogen receptor (ER) and progesterone receptor (PR) expression in the majority of tumour cells, and also overexpressed the human epidermal growth factor receptor (HER2/neu) (Table 2). There were no relevant histological signs of regression 3 months following neo-adjuvant chemotherapy.

\section{Periadrenal liposarcoma}

The periadrenal tumour was subsequently resected. Histological diagnosis revealed a poorly differentiated, pleomorphic, periadrenal liposarcoma. The lipogenic nature of tumour was confirmed by immunohistochemical detection of the S100 protein in the tumour cells. Adjuvant chemotherapy with taxanes was recommended following consultation with an interdisciplinary tumour board, because of the nodal positive breast cancer. Post-operative radiation of the periadrenal region due to RX resection of the periadrenal liposarcoma was also scheduled upon completion of the chemotherapy. Treatment with Trastuzumab and endocrine treatment was included according to the receptor status of the bilateral breast cancers. Moreover, radiation therapy after bilateral breast conserving therapy and radiation of the right upper arm was planned.

\section{Genetic counselling and molecular analysis}

Family history revealed a paternal uncle who died at 22 years from a malignancy in the splenic region. No further information regarding this tumour was available. Additionally, the paternal grandfather was diagnosed with leukaemia at 70 years. The maternal grandmother died from colorectal cancer diagnosed at 51 years. Criteria for Li-Fraumeni-like syndrome according to Eeles and the updated Chompret criteria were met (Table 1) [8]. Genetic analysis of TP53 was performed by sequencing genomic DNA isolated from peripheral blood leukocytes of our patient. A pathogenic, heterozygous germline mutation (p.Arg282Trp) was identified. Neither parent was shown to be a carrier of this mutation. Paternity was confirmed by using 15 high polymorphic ShortTandem-Repeats. Taken together, these data indicate that the TP53 mutation in the patient occurred de novo, 
although a germline mosaicism in one of the parents cannot be excluded. We examined tissue from a different germ layer to identify possible somatic mosaicism in the patient. Analysis of DNA from the oral mucosa revealed the same heterozygous TP53 mutation identified in the leucocytes. Thus, although we cannot rule out somatic mosaicism, this was very unlikely. Predictive testing was performed in the 44 year-old sibling and in both daughters (aged 21 and 18 years) of the patient. All three female subjects were not carriers of the mutation. Analyses of BRCA1 and BRCA2 genes in the index patient did not reveal any pathological findings.

\section{Therapy modification for supposed radiation sensitivity}

After confirmation of LFS by molecular analysis, the decision of an interdisciplinary consulting panel was to restrict the planned radiotherapy to the location with the highest priority. This decision was based on the suspected radiosensitivity of individuals harbouring a deleterious mutation in TP53. Thus, radiation was scheduled for the periadrenal region with postoperative $\mathrm{RX}$, however the initially intended radiotherapy of both breasts, as well as of the right upper arm was cancelled.

\section{Surveillance strategies}

The patient was offered secondary, bilateral prophylactic mastectomy, to reduce the risk of recurrent breast cancer. Due to the risk of new primary tumours at other sites, the patient refused this option and opted for a close, post-treatment observation regimen. The surveillance program was adjusted to her elevated risk for other primary malignancies and secondary malignancies after radiotherapy. Biannual ultrasound examination of the breast, annual magnetic resonance imaging (MRI) of the breast, and mammography at larger intervals were recommended. Abdominal ultrasound and MRI were predominantly used to monitor the sites of sarcomas.

\section{Recurrent disease of the periadrenal liposarcoma}

In June 2008, multiple nodular lesions were detected close to the left kidney by control MRI, inside and adjacent to the former irradiation region. The optimal response to several lines of treatment with chemotherapy was stable disease. A radical resection of the tumour mass was performed in June 2009. Histological analysis confirmed a recurrent, but well-differentiated liposarcoma. The short interval to radiation therapy of the left periadrenal region indicated resistance of the disease to radiation therapy.

In June 2010, MRI of the abdomen revealed local recurrence. As of February 2012, the patient has been under long-term treatment with trabectedine at a Karnofsky Index of $80 \%$. No distant metastasis, new primaries or recurrences at other sites have since been identified.

\section{Conclusions}

In this report, we describe a 40-year old, female patient with four concurrent primary malignant tumours. The simultaneous occurrence of four malignancies is uncommon, and metastases should be excluded. Indeed, all four tumours exhibited morphological features consistent with their histogenesis. Both breast cancers were hormone receptor positive and included intraductal components as precursor lesions for invasive carcinomas. A recent study by Melhem-Bertrandt et al., described an ER positive/ HER2 positive phenotype for breast cancer in TP53 germline mutation carriers [18]. This study also observed that in cases of bilaterality, both tumours were HER2 positive. In our patient, examination of the entire myxofibrosarcoma did not reveal any lipogenic morphology, and similarly, the liposarcoma did not exhibit a myxoid or nonlipogenic component. Furthermore, the liposarcoma expressed the S100 protein, which is an established marker for lipogenic differentiation. The typical combination of sarcomas and early-onset breast cancer was indicative of LFS and subsequent genetic analysis confirmed a germline mutation in the TP53 gene. While the patient met some of the wider Li-Fraumeni-like-criteria, she did not meet the classical LFS criteria [4]. The age at onset for the first malignancy was relatively high, as the estimated penetrance at 40 years of age ranges between $77 \%-100 \%$ [5]. The average age for diagnosis of first cancers in TP53 mutation carriers is estimated to be 21.9 years, and this is earlier in females than in males [1,5]. Predictive testing of minors is recommended since a high prevalence of adrenal gland, soft tissue and brain tumours has been observed in children

Testing of both parents indicated a de novo TP53 mutation in the patient. De novo TP53 mutations have been described in up to $23.5 \%$ (4 of 17 ) of carriers $[9,19]$. Recently, de novo TP53 mutations were confirmed in 7\% and suspected in up to $20 \%$ of a larger cohort with 75 germline mutation carriers [20].

\section{Treatment response to adjuvant therapy and prognosis}

Impaired response to chemotherapy and radiation is described in most studies [21-24]. In breast cancer, TP53 status was identified as independent negative prognostic marker [25], however the results remain controversial. The response to treatment ranges from a high rate of pathologic complete remission of breast cancer after neoadjuvant chemotherapy with anthracyclines, to primary tumour resistance and progression as observed in the case of our patient [26-31]. Introduction of wild-type TP53 by gene therapy increased the response to chemotherapy or radiation therapy in preclinical and some early clinical trials [27,32-34], however the results were not consistent and to date, gene therapy is not within reach for patients with LFS. 


\section{Treatment-induced secondary cancers}

The risk of developing secondary, radiation-induced malignancies was described as elevated in LFS patients, since the first reports of LFS by Li and Fraumeni [3]. Several case-reports point to the appearance of metachronous cancers in radiation-treated areas in cancer patients with TP53 mutations [35-39].

Data regarding secondary cancers after radiation therapy in young LFS patients is limited, because of the unfavourable prognosis of most core cancers in LFS and the expected time delay in radiation-induced cancers [19]. Interestingly, five long-term in-field relapses or second primary cancers were recently reported in six patients with unilateral breast cancer, following radiation treatment [39]. In a study of 27 LFS patients, nine were treated with radiotherapy. Of these, six patients suffered from one or two successive solid tumours in the radiation field within a period of 3-22 years (median 7 years) after treatment for the first malignancy. One additional cancer was identified in the radiation field of a patient following treatment for a third cancer, after a delay of 7 years [17]. In a separate study, three radiotherapytreated patients in a series of nine children with adrenocortical tumours and known TP53 mutations, survived more than two years, however these children developed five secondary malignancies in the radiation fields [19]. Preclinical studies support the hypothesis that cells lacking wild-type TP53 function have an increased likelihood of genetic instability due to high rates of inappropriate recombination after radiation-induced DNA damage (reviewed in Cuddihy et al., [40]). In Trp53-heterozygous or Trp53-null mice, treatment with low-dose irradiation led to shorter latency of tumour development and a higher incidence of malformations [41-43]. Human TP53-deficient cells have been shown to accumulate DNA damage and are susceptible to malignant transformation, whereas TP53-competent cells showed cellcycle arrest facilitating DNA repair, or apoptosis [44]. These data support the observation that LFS patients are more likely to develop radiotherapy-induced secondary cancers. Finally, it appears that in addition to TP53 variations, the presence of additional genetic alterations are required to predict the individual risk for radiationinduced secondary cancers $[45,46]$.

\section{Need for therapy modification in LFS patients}

Due to the potentially higher cancer induction rate after radiotherapy, it is important to consider the existence of a germline TP53-mutation, especially if there is a choice between surgery and radiotherapy [47,48]. After bilateral, breast-conserving resection, the initial plan to apply adjuvant radiation therapy was cancelled due to the detection of a germline TP53 mutation. Greater effort should be taken in the early detection and complete resection of
TP53-associated malignancies, since DNA-damaging, standard adjuvant therapies not only have a questionable effect, but also carry the risk for secondary tumours.

\section{Surveillance}

Most of the core cancers of LFS are associated with a poor prognosis. Interestingly, the first prospective data on the successful application of a surveillance programme in TP53 mutation carriers was recently published. The key imaging procedure was an annual rapid total body MRI starting in childhood. Compared to the control group, this study demonstrated a potential survival benefit using a comprehensive screening program [49].

Genetic counselling and predictive testing should be offered to patients fulfilling the classic LFS or LiFraumeni-like criteria, as well as to their relatives, in order to recommend an intensified cancer screening if LFS is confirmed. While the NCCN guidelines recommend the testing of singular cases suggestive for LFS, even in the absence of family history, others negate the necessity for testing because of low mutation rates $(0-7 \%)$ and high psychological burden. Numerous publications have explored the testing of early onset breast cancer cases for TP53 germline mutations and found that these represent rare cases $[1,11,50-57]$. For example, no pathologic mutations were found in 95 patients with breast cancer ( $<30$ years old), despite the fact that several patients displayed a positive family history for breast and ovarian cancer [50]. As the costs of testing decrease in the future and effective prevention strategies may be confirmed, testing patients with early onset breast cancer without a family history of cancer will become even more feasible.

In comparison to other tumour syndromes, such as hereditary breast and ovarian cancer, prophylactic operations do not offer a good prognosis for carriers of a TP53 germline mutation, and each case should be considered individually. Firstly, the life-time breast cancer risk is estimated to be $\sim 22 \%$. This is significantly lower than for carriers of a pathogenic mutation in BRCA1 or BRCA2, who display a life-time risk for breast cancer of $\sim 60-80 \%$. Secondly, in LFS, malignancies emerge in different anatomical sites, whereas $B R C A$-associated tumours mainly affect the breast and ovaries.

Since some LFS patients seem to carry an elevated risk for radiation-induced malignancies, exposure should be as low as possible, although a general contraindication for any type of radiological diagnostic or treatment cannot be stated. Surveillance strategies should be chosen with regard to the least possible radiation exposure.

\section{Consent}

Written informed consent was obtained from the patient for publication of this case report and any accompanying images. 


\section{Competing interests}

The authors declare that they have no competing interests.

\section{Acknowledgements}

We thank Alexandre Serra and Dorothea Gadzicki for carefully revising the manuscript.

\section{Author details}

${ }^{1}$ Klinik und Poliklinik für Frauenheilkunde und Geburtshilfe, Universitätsklinikum Carl Gustav Carus, Fetscherstr, 74, 01307 Dresden, Germany. ${ }^{2}$ Klinik und Poliklinik für Strahlentherapie und Radioonkologie, Universitätsklinikum Carl Gustav Carus, Fetscherstr, 74, 01307 Dresden, Germany. ${ }^{3}$ Medizinisch Klinik und Poliklinik I, Universitätsklinikum Carl Gustav Carus, Fetscherstr, 74, 01307 Dresden, Germany. ${ }^{4}$ Institut für Pathologie, Universitätsklinikum Carl Gustav Carus, Fetscherstr, 74, 01307 Dresden, Germany. ${ }^{5}$ MVZ Dr. Reising-Ackermann u, Kollegen, Strümpelstr, 40, 04289 Leipzig, Germany. ${ }^{6}$ Gemeinschaftspraxis für Humangenetik, Gutenbergstr, 5 , 01307 Dresden, Germany.

\section{Authors' contributions}

KK has made substantial contributions to conception and design and was writing the manuscript. She made substantial contributions to acquisition, analysis and interpretation of the data. MK revised the manuscript critically for important intellectual content. MS revised the manuscript critically for important intellectual content. KF revised the manuscript critically for important intellectual content and was involved in acquisition and analysis of data. BT was involved in acquisition and analysis of data. AB has made substantial contributions to conception and design and has been involved in drafting the manuscript. She was involved in analysis of data. WD has given final approval of the version to be published. SK has made substantial contributions to conception and design and has been involved in drafting the manuscript. He made substantial contributions to analysis of data. All authors read and approved the final manuscript.

Received: 5 December 2011 Accepted: 6 June 2012

Published: 6 June 2012

\section{References}

1. Gonzalez KD, Noltner KA, Buzin CH, Gu D, Wen-Fong CY, Nguyen VQ, Han JH, Lowstuter K, Longmate J, Sommer SS, et al: Beyond Li Fraumeni Syndrome: clinical characteristics of families with $\mathrm{p} 53$ germline mutations. J Clin Oncol 2009, 27(8):1250-1256.

2. Nagy R, Sweet K, Eng C: Highly penetrant hereditary cancer syndromes. Oncogene 2004, 23(38):6445-6470.

3. Li FP, Fraumeni JF Jr: Soft-tissue sarcomas, breast cancer, and other neoplasms. A familial syndrome? Ann Intern Med 1969, 71(4):747-752.

4. Li FP, Fraumeni JF Jr, Mulvihill JJ, Blattner WA, Dreyfus MG, Tucker MA, Miller RW: A cancer family syndrome in twenty-four kindreds. Cancer Res 1988, 48(18):5358-5362.

5. Hwang SJ, Lozano G, Amos Cl, Strong LC: Germline p53 mutations in a cohort with childhood sarcoma: sex differences in cancer risk. Am J Hum Genet 2003, 72(4):975-983.

6. Wu CC, Shete S, Amos Cl, Strong LC: Joint effects of germ-line p53 mutation and sex on cancer risk in Li-Fraumeni syndrome. Cancer Res 2006, 66(16):8287-8292.

7. Birch JM, Hartley AL, Tricker KJ, Prosser J, Condie A, Kelsey AM, Harris M, Jones PH, Binchy A, Crowther D, et al: Prevalence and diversity of constitutional mutations in the p53 gene among 21 Li-Fraumeni families. Cancer Res 1994, 54(5):1298-1304.

8. Eeles RA: Germline mutations in the TP53 gene. Cancer Surv 1995, 25:101-124.

9. Chompret A, Brugieres L, Ronsin M, Gardes M, Dessarps-Freichey F, Abel A, Hua D, Ligot L, Dondon MG, Bressac-de Paillerets B, et al: P53 germline mutations in childhood cancers and cancer risk for carrier individuals. $\mathrm{Br}$ J Cancer 2000, 82(12):1932-1937.

10. Chompret A, Abel A, Stoppa-Lyonnet D, Brugieres L, Pages S, Feunteun J, Bonaiti-Pellie C: Sensitivity and predictive value of criteria for p53 germline mutation screening. J Med Genet 2001, 38(1):43-47.

11. Tinat J, Bougeard G, Baert-Desurmont S, Vasseur S, Martin C, Bouvignies E, Caron O, Bressac-de Paillerets B, Berthet P, Dugast C, et al: 2009 version of the Chompret criteria for Li Fraumeni syndrome. J Clin Oncol 2009, 27(26): e108-e109. author reply e110.
12. Varley JM: Germline TP53 mutations and Li-Fraumeni syndrome. Hum Mutat 2003, 21(3):313-320.

13. Olivier M, Goldgar DE, Sodha N, Ohgaki H, Kleihues P, Hainaut P, Eeles RA: Li-Fraumeni and related syndromes: correlation between tumor type, family structure, and TP53 genotype. Cancer Res 2003, 63(20):6643-6650.

14. Bougeard G, Sesboue R, Baert-Desurmont S, Vasseur S, Martin C, Tinat J, Brugieres L, Chompret A, de Paillerets BB, Stoppa-Lyonnet D, et al: Molecular basis of the Li-Fraumeni syndrome: an update from the French LFS families. J Med Genet 2008, 45(8):535-538.

15. Malkin D, Li FP, Strong LC, Fraumeni JF Jr, Nelson CE, Kim DH, Kassel J, Gryka MA, Bischoff FZ, Tainsky MA, et al: Germ line p53 mutations in a familial syndrome of breast cancer, sarcomas, and other neoplasms. Science 1990, 250(4985):1233-1238.

16. Lacroix M, Toillon RA, Leclercq G: p53 and breast cancer, an update. Endocr Relat Cancer 2006, 13(2):293-325.

17. Hisada M, Garber JE, Fung CY, Fraumeni JF Jr, Li FP: Multiple primary cancers in families with Li-Fraumeni syndrome. J Natl Cancer Inst 1998, 90 (8):606-611.

18. Melhem-Bertrandt A, Bojadzieva J, Ready KJ, Obeid E, Liu DD, GutierrezBarrera AM, Litton JK, Olopade OI, Hortobagyi GN, Strong LC, et al: Early onset HER2-positive breast cancer is associated with germline TP53 mutations. Cancer 2012, 118(4):908-913.

19. Varley JM, McGown G, Thorncroft M, Santibanez-Koref MF, Kelsey AM, Tricker KJ, Evans DG, Birch JM: Germ-line mutations of TP53 in LiFraumeni families: an extended study of 39 families. Cancer Res 1997, 57 (15):3245-3252.

20. Gonzalez KD, Buzin CH, Noltner KA, Gu D, Li W, Malkin D, Sommer SS: High frequency of de novo mutations in Li-Fraumeni syndrome. J Med Genet 2009, 46(10):689-693.

21. Lowe SW, Bodis S, McClatchey A, Remington L, Ruley HE, Fisher DE, Housman DE, Jacks T: p53 status and the efficacy of cancer therapy in vivo. Science 1994, 266(5186):807-810.

22. Hamada M, Fujiwara T, Hizuta A, Gochi A, Naomoto Y, Takakura N, Takahashi K, Roth JA, Tanaka N, Orita K: The p53 gene is a potent determinant of chemosensitivity and radiosensitivity in gastric and colorectal cancers. $J$ Cancer Res Clin Oncol 1996, 122(6):360-365.

23. Preudhomme C, Fenaux P: The clinical significance of mutations of the P53 tumour suppressor gene in haematological malignancies. $\mathrm{Br} J$ Haematol 1997, 98(3):502-511.

24. Shelling AN: Role of p53 in drug resistance in ovarian cancer. Lancet 1997, 349(9054):744-745.

25. Olivier M, Langerod A, Carrieri P, Bergh J, Klaar S, Eyfjord J, Theillet C, Rodriguez C, Lidereau R, Bieche I, et al: The clinical value of somatic TP53 gene mutations in 1,794 patients with breast cancer. Clin Cancer Res 2006, 12(4):1157-1167.

26. Aas T, Borresen AL, Geisler S, Smith-Sorensen B, Johnsen H, Varhaug JE, Akslen LA, Lonning PE: Specific P53 mutations are associated with de novo resistance to doxorubicin in breast cancer patients. Nat Med 1996, 2(7):811-814.

27. Cimoli G, Malacarne D, Ponassi R, Valenti M, Alberti S, Parodi S: Metaanalysis of the role of p53 status in isogenic systems tested for sensitivity to cytotoxic antineoplastic drugs. Biochim Biophys Acta 2004, 1705(2):103-120.

28. Geisler S, Borresen-Dale AL, Johnsen H, Aas T, Geisler J, Akslen LA, Anker G, Lonning PE: TP53 gene mutations predict the response to neoadjuvant treatment with 5 -fluorouracil and mitomycin in locally advanced breast cancer. Clin Cancer Res 2003, 9(15):5582-5588.

29. Geisler S, Lonning PE, Aas T, Johnsen H, Fluge O, Haugen DF, Lillehaug JR, Akslen LA, Borresen-Dale AL: Influence of TP53 gene alterations and cerbB-2 expression on the response to treatment with doxorubicin in locally advanced breast cancer. Cancer Res 2001, 61(6):2505-2512.

30. Kandioler-Eckersberger D, Ludwig C, Rudas M, Kappel S, Janschek E, Wenzel C, Schlagbauer-Wadl H, Mittlbock M, Gnant M, Steger G, et al: TP53 mutation and p53 overexpression for prediction of response to neoadjuvant treatment in breast cancer patients. Clin Cancer Res 2000, 6 (1):50-56.

31. Lanni JS, Lowe SW, Licitra EJ, Liu JO, Jacks T: p53-independent apoptosis induced by paclitaxel through an indirect mechanism. Proc Natl Acad Sci U S A 1997, 94(18):9679-9683.

32. Lu C, El-Deiry WS: Targeting p53 for enhanced radio- and chemosensitivity. Apoptosis 2009, 14(4):597-606. 
33. Peng Z: Current status of gendicine in China: recombinant human Ad-p53 agent for treatment of cancers. Hum Gene Ther 2005, 16(9):1016-1027.

34. Pan JJ, Zhang SW, Chen CB, Xiao SW, Sun Y, Liu CQ, Su X, Li DM, Xu G, Xu $B$, et al: Effect of recombinant adenovirus-p53 combined with radiotherapy on long-term prognosis of advanced nasopharyngeal carcinoma. J Clin Oncol 2009, 27(5):799-804.

35. Agir H, MacKinnon C, Tan ST: Li-Fraumeni syndrome: a case with 4 separate primary sarcomas and 5 sequential free flaps in the maxillofacial region. J Oral Maxillofac Surg 2008, 66(8):1714-1719.

36. Limacher JM, Frebourg T, Natarajan-Ame S, Bergerat JP: Two metachronous tumors in the radiotherapy fields of a patient with Li-Fraumeni syndrome. Int J Cancer 2001, 96(4):238-242.

37. Salmon A, Amikam D, Sodha N, Davidson S, Basel-Vanagaite L, Eeles RA, Abeliovich D, Peretz T: Rapid development of post-radiotherapy sarcoma and breast cancer in a patient with a novel germline 'de-novo' TP53 mutation. Clin Oncol (R Coll Radiol) 2007, 19(7):490-493.

38. Nutting $C$, Camplejohn RS, Gilchrist $R$, Tait D, Blake $P$, Knee $G$, Yao WQ, Ross $G$, Fisher $C$, Eeles $R$ : A patient with 17 primary tumours and a germ line mutation in TP53: tumour induction by adjuvant therapy? Clin Oncol ( $R$ Coll Radiol) 2000, 12(5):300-304

39. Heymann S, Delaloge S, Rahal A, Caron O, Frebourg T, Barreau L, Pachet C, Mathieu MC, Marsiglia H, Bourgier C: Radio-induced malignancies after breast cancer postoperative radiotherapy in patients with Li-Fraumeni syndrome. Radiat Oncol 2010, 5:104.

40. Cuddihy AR, Bristow RG: The $p 53$ protein family and radiation sensitivity: Yes or no? Cancer Metastasis Rev 2004, 23(3-4):237-257.

41. Kemp CJ, Wheldon T, Balmain A: p53-deficient mice are extremely susceptible to radiation-induced tumorigenesis. Nat Genet 1994, 8(1):66-69.

42. Kato F, Ootsuyama A, Nomoto S, Kondo S, Norimura T: Threshold effect for teratogenic risk of radiation depends on dose-rate and p53-dependent apoptosis. Int J Radiat Biol 2001, 77(1):13-19.

43. Baatout $S$, Jacquet $P$, Michaux A, Buset J, Vankerkom J, Derradji H, Yan J, von Suchodoletz H, de Saint-Georges L, Desaintes C, et al: Developmental abnormalities induced by $\mathrm{X}$-irradiation in p53 deficient mice. In Vivo 2002, 16(3):215-221.

44. Boyle JM, Spreadborough A, Greaves MJ, Birch JM, Varley JM, Scott D: The relationship between radiation-induced $\mathrm{G}$ (1)arrest and chromosome aberrations in Li-Fraumeni fibroblasts with or without germline TP53 mutations. Br J Cancer 2001, 85(2):293-296.

45. Boyle JM, Spreadborough AR, Greaves MJ, Birch JM, Varley JM, Scott D: Delayed chromosome changes in gamma-irradiated normal and $\mathrm{Li}-$ Fraumeni fibroblasts. Radiat Res 2002, 157(2):158-165.

46. Backlund MG, Trasti SL, Backlund DC, Cressman VL, Godfrey V, Koller BH: Impact of ionizing radiation and genetic background on mammary tumorigenesis in p53-deficient mice. Cancer Res 2001, 61(17):6577-6582.

47. Evans DG, Birch JM, Ramsden RT, Sharif S, Baser ME: Malignant transformation and new primary tumours after therapeutic radiation for benign disease: substantial risks in certain tumour prone syndromes. $J$ Med Genet 2006, 43(4):289-294.

48. Moule RN, Jhavar SG, Eeles RA: Genotype phenotype correlation in LiFraumeni syndrome kindreds and its implications for management. Fam Cancer 2006, 5(2):129-133.

49. Villani A, Tabori U, Schiffman J, Shlien A, Beyene J, Druker H, Novokmet A, Finlay J, Malkin D: Biochemical and imaging surveillance in germline TP53 mutation carriers with Li-Fraumeni syndrome: a prospective observational study. Lancet Oncol 2011, 12(6):559-567.

50. Ginsburg OM, Akbari MR, Aziz Z, Young R, Lynch H, Ghadirian P, Robidoux A, Londono J, Vasquez $G$, Gomes $M$, et al: The prevalence of germ-line TP53 mutations in women diagnosed with breast cancer before age 30 . Fam Cancer 2009, 8(4):563-567.

51. Arcand SL, Maugard CM, Ghadirian P, Robidoux A, Perret C, Zhang P, Fafard E, Mes-Masson AM, Foulkes WD, Provencher D, et al: Germline TP53 mutations in BRCA1 and BRCA2 mutation-negative French Canadian breast cancer families. Breast Cancer Res Treat 2008, 108(3):399-408.

52. Borresen AL, Andersen TI, Garber J, Barbier-Piraux N, Thorlacius S, Eyfjord J, Ottestad L, Smith-Sorensen B, Hovig E, Malkin D, et al: Screening for germ line TP53 mutations in breast cancer patients. Cancer Res 1992, 52 (11):3234-3236.

53. Lalloo F, Varley J, Ellis D, Moran A, O'Dair L, Pharoah P, Evans DG: Prediction of pathogenic mutations in patients with early-onset breast cancer by family history. Lancet 2003, 361(9363):1101-1102.
54. Lalloo F, Varley J, Moran A, Ellis D, O'Dair L, Pharoah P, Antoniou A, Hartley $R$, Shenton $A$, Seal $S$, et al: BRCA1, BRCA2 and TP53 mutations in very early-onset breast cancer with associated risks to relatives. Eur J Cancer 2006, 42(8):1143-1150.

55. Mouchawar J, Korch C, Byers T, Pitts TM, Li E, McCredie MR, Giles GG, Hopper JL, Southey MC: Population-based estimate of the contribution of TP53 mutations to subgroups of early-onset breast cancer: Australian Breast Cancer Family Study. Cancer Res 2010, 70(12):4795-4800.

56. Prosser J, Elder PA, Condie A, MacFadyen I, Steel CM, Evans HJ: Mutations in p53 do not account for heritable breast cancer: a study in five affected families. Br J Cancer 1991, 63(2):181-184

57. Walsh T, Casadei S, Coats KH, Swisher E, Stray SM, Higgins J, Roach KC, Mandell J, Lee MK, Ciernikova S, et al: Spectrum of mutations in BRCA1, BRCA2, CHEK2, and TP53 in families at high risk of breast cancer. JAMA 2006, 295(12):1379-1388

doi:10.1186/1471-2407-12-217

Cite this article as: Kast et al.: Late onset Li-Fraumeni Syndrome with bilateral breast cancer and other malignancies: case report and review of the literature. BMC Cancer 2012 12:217.

\section{Submit your next manuscript to BioMed Central and take full advantage of:}

- Convenient online submission

- Thorough peer review

- No space constraints or color figure charges

- Immediate publication on acceptance

- Inclusion in PubMed, CAS, Scopus and Google Scholar

- Research which is freely available for redistribution 